Date of this draft: February 29, 2008

\title{
TRADE COSTS AND PROVINCIAL HETEROGENEITY IN ITALY
}

\author{
Michele Fratianni* and Francesco Marchionne**
}

\begin{abstract}
We test the hypothesis that higher economic development is associated with lower trade costs. Using different methods to control for multilateral resistance, we apply two alternative gravity equations (GE). In the first, we estimate total exports from 103 Italian provinces to 188 countries over the period 1995-2004. In the second, we estimate sectoral exports and then construct provincial trade cost elasticities. Italian provinces are heterogeneous with respect to trade costs. The two versions of GE are qualitatively the same but quantitatively different suggesting that other factors than trade costs are at play, possibly agglomeration externalities.
\end{abstract}

Key Words: trade costs, heterogeneity, distance, gravity equation.

JEL Classification: F10, F14, O52, R12.

\footnotetext{
* Corresponding author, Indiana University, Kelley School of Business, Bloomington, Indiana (USA) and Università Politecnica delle Marche, Ancona (Italy), email: fratiann@indiana.edu. ** Università Politecnica delle Marche, Ancona (Italy), email: f.marchionne@univpm.it. We thank Pietro Alessandrini, Chang Hoon Oh, Riccardo Lucchetti and Alberto Zazzaro for comments and suggestions on an earlier draft of the paper.
} 


\section{INTRODUCTION}

In this paper we test the hypothesis that trade costs (TCs) are negatively related to the degree of economic development. To motivate our hypothesis we draw on the link between TCs and crossborder trade flows and the link between TCs and spatial economic disparities.

There is ample evidence that TCs play an important role in international trade. A decline in international transportation costs, a component of TCs, is a likely cause underlying the sharp rise of world trade relative to world output that has occurred over the last fifty years (Hummels, 2007). Transportation costs rise with distance and, consequently, close countries tend to trade more than distant countries. But there is more than transportation in distance. Common language (Helliwell, 1999; Hutchinson, 2002), common colonial roots (Rauch 1999), shared religion (Kang and Fratianni, 2006), immigrant links to the home country (Gould, 1994; Head and Ries, 1998) or more generally ethnic networks (Rauch and Trindade, 2001), and similarity in economic development (Fratianni and Kang, 2006) are trade-enhancing characteristics that counteract transportation costs. Beyond culture, cross-border trade is influenced by institutions such as regional trade agreements (Carrère, 2006; Baier and Bergstrand, 2007) and common money (Rose, 2000; Rose and van Wincoop, 2001; Frankel and Rose, 2002). Last but not least, national borders are a big impediment to trade (McCallum, 1995; Helliwell, 1998; Anderson and van Wincoop, 2003; Chen, 2004). In their extensive survey, Anderson and van Wincoop (2004, 691-2; AvW henceforth) estimate that TCs represent the equivalent of a 170 percent ad-valorem tax barrier to trade, of which 21 percent attributable to transportation costs, 44 percent to border-related impediments, and 55 percent to distribution costs. In sum, TCs are large and complex. An often cited paper by Obstfeld and Rogoff (2000) argues that TCs are the common cause to six major puzzles in international macroeconomics.

TCs are also critical in affecting the location of production facilities. Krugman (1991), the leader of the 'new economic geography', develops a core-periphery model that hinges critically on the interaction of transportation costs with scale economies in production. The model features a 
sector, agriculture, with constant returns to scale and an immobile factor of production, land, and another sector, manufacturing, with increasing returns to scale and a mobile factor, labor. Pecuniary spillovers trigger a "circular causation" process whereby manufacturing tends to concentrate in locations with large markets that, in turn, lead to more concentration because those locations enjoy lower effective prices and attract mobile labor. The outcome is the endogenous formation of a richer industrial core and a poorer agricultural periphery, or more generally regional economic differences. The income differences result from differences in prices, with workers in the core enjoying higher real wages than in the periphery. Agglomeration accentuates as transportation costs decline, giving more incentive to footloose manufacturing to relocate. Agglomeration can also arise through cost and demand linkages stemming from firms using intermediate goods (Venables, 1996) or through innovation (Martin and Ottaviano, 2001). Regional economic development is a path-dependent process. Economic geographers agree with this conclusion, but have been critical of the 'new economic geography' for not specifying the nature of this path dependence, especially in terms of local institutions and social structures (Martin and Sunley, 1996, 286).

At the empirical level, economic historians have pointed out the economic dominance of medieval Italian city-states like Venice, Genoa and Florence, of Antwerp in the first half of the $16^{\text {th }}$ century, and of Amsterdam and London for much of the $18^{\text {th }}$ century (Braudel, 1992; Kindleberger, 1996). There is also historical evidence that economic growth is associated with urbanization, spatial disparities and rising income inequality (Kuznets, 1966). Spatial disparities are also evident today in fast growing emerging economies such as Mexico, where the manufacturing center is located along the border with the United States, in China, where its center is in the coastal provinces, and in India, where its center is in the southern states (Venables, 2005, 3).

The posited negative correlation between development and TCs is a natural extension of the core-periphery model. The core (or cores) attracts firms and labor from the periphery (or peripheries) because it enjoys higher productivity, including sectors such as information services and distribution that are so important for international trade. The core also benefits from better 
infrastructure and public administration, which tend to be positively correlated with development. Simply put, it is cheaper to run business in the cores. We test our hypothesis by estimating bilateral trade flows from the viewpoint of an individual country that shares common culture and national institutions but is heterogeneous with respect to economic development. Italy, a country known for its North-South divide, is a natural candidate. This divide goes back to the very beginning of the nation and persists to these days despite large government transfers to the South (Mezzogiorno) over the last fifty years. Much has been written on the subject but space permits only a few references. ${ }^{1}$ Lutz (1962) was among the first to analyze in depth the Italian dual economy, which she found to exist not only geographically, but also across industries. The literature has gone beyond the NorthSouth characterization. For example, Bagnasco (1977) identifies three distinct economic areas in Italy: the old capital-intensive North-West (First Italy), the agricultural and backward South (Second Italy), and the newer North-East with parts of the Center (Third Italy). Third Italy, furthermore, is replete with dynamic small and medium size firms that outsource production and are located in industrial districts (Brusco, 1990). These districts, in turn, are distinctive in their development paths, local institutions, and manners to generate externalities (Becattini, 1990 and 2007). ${ }^{2}$ In sum, regional economic development is heterogeneous.

Our research strategy is to estimate gravity equations (GE) using bilateral trade between 103 Italian provinces and partner countries imposing the strong assumption that each province is distinctive only in its degree of economic development. The implication is that the elasticity of exports with respect to provincial TCs (simply, TC elasticity), our measure of TCs, is negatively related to provincial per-capita income, our synthetic measure of economic development. In Section II, we discuss the general form of GE in the presence of multilateral TCs. In Section III, we formulate two alternative models, a top-down GE and a bottom-up GE. Section IV is devoted to data. Findings are analyzed in Section V. Conclusions are drawn in the last section.

\footnotetext{
${ }^{1}$ JSTOR lists 470 entries in economics journals under the label of Mezzogiorno.

${ }^{2}$ Markusen (1996) discusses different types of industrial districts (agglomeration).
} 


\section{THE GRAVITY EQUATION AND MULTILATERAL TRADE COSTS}

In a well-known paper, McCallum (1995) applied a GE to 1988 exports and imports among ten Canadian provinces and thirty U.S. states and found that inter-provincial trade was approximately twenty times larger than trade between provinces and states; in essence, the US-Canadian border is very thick. AvW (2003) criticized McCallum's findings mostly for ignoring multilateral TCs. They argue that general-equilibrium considerations dictate that trade flows from region $i$ to region $j$ depend, among other factors, not only on bilateral TCs but also on multilateral ones. ${ }^{3}$ When multilateral costs rise relative to bilateral costs, trade flows rise between $i$ and $j$. These authors derive the following operational GE (see their equation 13):

$$
x_{i j}=\frac{y_{i} \cdot y_{j}}{y^{W}}\left(\frac{t_{i j}}{P_{i} \cdot P_{j}}\right)^{1-\sigma},
$$

where $x=$ exports from $i$ to $j, y=$ nominal income, $t=$ bilateral TC factor, $P=$ multilateral TC factor (i.e., consumer price index), $\sigma=$ elasticity of substitution among goods, and $i, j$, and $W$ indicate, respectively, exporter country, importer country and the world. Assuming that $t_{i j}$ is a function of bilateral distance and one plus the tariff-equivalent bilateral border barrier, AvW estimate with nonlinear least squares a simultaneous system of equations on cross-section data. Their main result is that borders reduce trade in the range of 20 to 50 percent, that is much less than the border found by McCallum.

The AvW estimation procedure is rather cumbersome and other authors have sought simpler alternatives. Baier and Bergstrand (2007) obtain virtually identical results with bonus vetus (good old) OLS using a first-order log-linear Taylor series expansion to approximate multilateral resistance with appropriate exogenous variables captured by country fixed effects. Baldwin and Taglioni (2006) take a broader look at the issue and identify three estimation errors with GEs, stemming primarily from multilateral trade factors. To each error the authors assign prizes in the

\footnotetext{
${ }^{3}$ The immediate predecessor of Anderson and van Wincoop is Anderson (1979). Other theoretical foundations of GE are provided by Bergstrand (1985, 1989), Deardorff (1998), Helpman (1987), and Haveman and Hummels (2004).
} 
form of Olympic medals. The bronze medal goes for using real GDPs, as opposed to nominal GDPs. The multilateral trade factors are not well identified and the model errors fail to be orthogonal to the regressors, with the consequence that the OLS estimator is asymptotically downward biased. ${ }^{4}$ The silver medal, assigned for a more serious error, goes for employing twoway bilateral trade. Since the GE is a modified expenditure function with a market-clearing condition, the theory explains only one-way bilateral trade and not two-way trade. This error leads to an overestimate of bilateral trade and larger error variance, which is particularly severe in panel data. Finally, the gold medal goes for omitting altogether the multilateral resistance factor. Following Rose and van Wincoop (2001), Feenstra (2003), and Cheng and Wall (2003), Baldwin and Taglioni propose country dummies in cross-section data and country-pair fixed effects in panel data to solve the gold medal error. However, country-pair dummies (simply, pair dummies) are time-invariant and consequently can only in part resolve the gold medal error; serial correlation remains. It should be added that pair dummies capture all fixed effects, including distance elasticity, making it impossible to distinguish among parameters of various time-invariant variables. The alternative is provided by Carrère (2006) who shows the merit of modelling pair dummies as random variables. In sum, employing random pair dummies we can estimate the impact of distance on trade and avoid receiving the gold medal.

\section{TOP-DOWN AND BOTTOM-UP GRAVITY EQUATIONS}

For our strategy we propose two GEs, a top-down and a bottom-up version. In the top-down GE, distance elasticity is estimated directly for each of the 103 Italian provinces. In addition, border elasticity is estimated to be the same for those provinces that are adjacent to foreign countries. The sum of distance and border elasticities defines province-specific TC elasticity, which is then correlated with provincial per-capita income to see whether there is an inverse relationship between TCs and economic development. The other factors are common to all provinces. In the bottom-up

\footnotetext{
${ }^{4}$ Other problems arise also from differences among price deflators (traded and non-traded goods) and price indices of traded goods.
} 
GE, provincial distance elasticity is constructed as the weighted average of sectoral export distance elasticities. We do it by first estimating distance elasticities for all export sectors under the restriction that these elasticities are common to all provinces. Then, we construct provincial distance elasticities as the weighted average of sectoral export distance elasticities, where the weights are given by shares of provincial sectoral exports. Border elasticity is then added to distance elasticity to obtain the bottom-up TC elasticity. The two methods should yield similar results in the absence of co-products or residuals generated, among other things, either by agglomeration externalities or by congestion costs. If positive externalities prevail we would expect the algebraic value of TC elasticities to be larger in the top-down GE than in the bottom-up GE; the reverse would hold if congestion costs prevail.

\section{$\underline{\text { Overall GE }}$}

Define TCs of the $k^{\text {th }}$ product exported by the $i^{\text {th }}$ Italian province to the $j^{\text {th }}$ country as follows (for similar specification, see Carrère (2006)):

$$
t_{i j k t}=d_{i j}^{\rho_{0}} \cdot e^{\left[\rho_{1} R T A_{j k t}+\rho_{2} \text { InterRTA }_{j k t}+\rho_{3} M O N E Y_{j k t}+\rho_{4} B O R D E R_{i j k}\right]}
$$

where $d_{i j}$ is bilateral distance, RTA (InterRTA) is a dummy that assumes 1 when $i$ and $j$ belong to the same (different) regional trade agreement, MONEY and BORDER are dummies that assume 1 when $i$ and $j$ share the same money or a land border. Institutional and cultural factors such as common language, colonial relationships and immigrant links are irrelevant and have been omitted. ${ }^{5}$ RTA, InterRTA, and MONEY are relevant but are common to all provinces; hence, we drop subscript $i$. BORDER is also relevant but affects only some Northern provinces; hence, subscript $i$ has been retained while $t$ has been dropped because this variable is time-invariant over the period. As to the signs of the coefficients, $\rho_{0}$ is positive and $\rho_{3}$ and $\rho_{4}$ are negative. The signs of $\rho_{1}$ and $\rho_{2}$, instead,

\footnotetext{
${ }^{5}$ Italian, as the majority's language, is only spoken in Italy. Catholicism is the prevalent religion. Colonial relationships with former colonies Libya, Somalia and Eritrea were too short lived to be of any relevance. Emigrants' relationships are primarily with the home country. Furthermore, these relationships have diminished over time and are captured in our model by country fixed effects.
} 
depend on whether the RTA is trade creating or trade diverting. If the RTA is trade creating, both $\rho_{1}$ and $\rho_{2}$ are negative; if the RTA is trade diverting $\rho_{1}$ is negative but $\rho_{2}$ is positive (Carrère, 2006).

Substituting (2) in (1) we obtain a testable GE that is similar to AvW's (2003) equation 19:

$$
\ln x_{i j k t}=A+\ln y_{i k t}+\ln y_{j k t}+(1-\sigma) \rho_{0} \ln d_{i j}+\sum_{f=1}^{4}(1-\sigma) \rho_{f} Z_{f, i j k t}+u_{i j k t},
$$

where $A=\ln \left(y_{t}^{W} P_{i k t}^{1-\sigma} P_{j k t}^{1-\sigma}\right)$ is the multilateral TC factor and $Z_{f}$ is the set of three TCs that are common to all provinces plus one TC that is common to Northern provinces adjacent to other countries $\left(Z_{1}=R T A, Z_{2}=\right.$ InterRTA, $Z_{3}=M O N E Y$ and $\left.Z_{4}=B O R D E R\right)$. Province-sensitive distance elasticity $\beta_{0}=(1-\sigma) \rho_{0}$ is negative since the elasticity of substitution $\sigma$ is larger than unity; the four semi-elasticities $\beta_{f}=(1-\sigma) \rho_{f}$ are positive, except for $\beta_{2}<0$ when the RTA is trade diverting; $u_{i j t}=\mu_{t}+\varepsilon_{i j t}$, where $\mu_{t}$ is a year dummy and $\varepsilon_{i j t}$ is an idiosyncratic error.

\section{Top-down GE}

In the top-down GE, we modify general specification (3) as follows. The left-hand side variable is total exports by the province (denoted with "." in place of the $k$ subscript) and on the right-hand side distance is replaced with the interaction of distance with provincial dummies:

$$
\ln x_{i j . t}=A+\ln y_{i . t}+\ln y_{j . t}+\sum_{i=1}^{I} \beta_{0, i} \delta(i) \ln d_{i j}+\sum_{f=1}^{4} \beta_{f} Z_{f, i j . t}+u_{i j . t},
$$

where $I$ is the number of provinces and $\delta(i)$ is a province dummy. Province-specific TC elasticities are:

$$
\beta_{S, i}=\beta_{0, i}+\beta_{4, i} * \overline{B O R D E R}_{i j}
$$

where $\overline{B O R D E R}_{i j}$ is the frequency of common-land border trade in total trade of province $i .{ }^{6}$ Meanadjusted $\beta_{S, i}$ are then regressed on average per-capita income of province $i, Y_{i} / N_{i}$, to see whether they are an increasing function of economic development: 


$$
\beta_{S, i}-\bar{\beta}_{S, i}=a+b \cdot \frac{Y_{i}}{N_{i}} \quad b>0
$$

Our methodology is closer to the "bonus vetus $O L S$ " of Baier and Bergrstrand than to the nonlinear least square estimation of AvW. However, we avoid receiving any medals in the BaldwinTaglioni mistake race. With respect to the gold medal, we control for multilateral resistance using (a) Feenstra's method of country fixed effects, (b) Carrère's method of country pair random effects and (c) combined Feenstra-Carrère's method of country fixed effects and country pair random effects. Method (c) is the best one because it considers all time-invariant specific effects of multilateral resistance. Method (b) is second best because it captures the bulk of the specific effects, although is less consistent than (c). Method (a) is the least desirable because it controls only for country effects, although it is better than a pure OLS since the latter fails to control for any specific effects. We avoid the silver medal because our dependent variable are exports and not two-way flows. Finally, we avoid the bronze medal because we employ nominal GDP instead of real GDP.

\section{Bottom-up GE}

In the bottom-up model, we first estimate sectoral distance elasticities under the restriction that these elasticities are common to all provinces; the restriction is imposed by data availability. We then calculate provincial distance elasticities as the weighted average of sectoral export distance elasticities, where the weights are given by the average shares of provincial sectoral exports. Distance in (3) is replaced by the interaction of distance with sectoral dummies. Coefficient $\beta_{0}$ varies among sectors, so the GE assumes the following form:

$$
\ln x_{i j k t}=A+\ln y_{i t k}+\ln y_{j t k}+\sum_{k=1}^{K} \beta_{0, k} \delta(k) \ln d_{i j}+\sum_{f=1}^{4} \beta_{f} Z_{f, i j k t}+u_{i j k t},
$$

$$
\overline{B O R D E R}_{i j}=\frac{\sum_{t=1}^{T} \sum_{j=1}^{J} n_{i j t} \cdot \text { BORDER }_{i j}}{\sum_{t=1}^{T} \sum_{j=1}^{J} n_{i j t}} .
$$

The numerator measures the number of export flows from the $i^{\text {th }}$ province to adjacent partner countries and the denominator the number of flows of the $i^{\text {th }}$ province to all partner countries. 
where $K$ is the number of sectors and $\delta(k)$ is a sector dummy. This approach is similar to the one adopted for provinces in the top-down model. Equations (5), like equation (4), is estimated with the (a), (b) and (c) methods.

The construction of provincial TC elasticities is done as follows. First, we estimate sectoral distance elasticities from pooled provincial data. Second, we construct yearly provincial distance elasticity as the weighted average of sectoral distance elasticities. Third, we compute the average provincial distance elasticity over the sample period. ${ }^{7}$ We then add to distance elasticity the border elasticity from the top-down model to obtain provincial TC elasticity. ${ }^{8}$ As in the top-down model, average provincial TC elasticities are regressed on average per-capita provincial income.

\section{DATA}

Our dataset consists of 972,754 observations covering 103 Italian provinces, 188 countries, and 21 sectors over the period 1995-2004. The data come from different sources. Annual exports by province, country, and sector are from the Italian National Institute of Statistics (ISTAT); they include all bilateral flows in excess of one euro recorded by custom offices. As already mentioned, we avoid the silver medal in the mistake race by considering only exports. On the other hand, we cannot avoid magnifying the effects of vertical specialization (Hummels, Ishii and Yi, 2001). A bias is generated by re-exporting, which occurs when part of the intermediate production process is localized abroad. In these instances, export data overestimate the true but unknown value of exports (AvW, 2004). We eliminate sector "Ships and aircrafts, etc." because it lacks a specific destination and exports to politically undefined areas (e.g., Antarctica) or remote parts of a country (e.g.,

${ }^{7}$ If $K, J$ and $T$ are respectively the number of sectors, importing countries and years, $\widehat{\beta}_{0, i}$ is:

$$
\hat{\beta}_{0, i}=\frac{1}{T} \cdot \sum_{t=1}^{T}\left(\sum_{k=1}^{K} \bar{w}_{i, k t} \cdot \beta_{0, k}\right) \text {, where } \bar{w}_{i, k t}=\frac{\sum_{j=1}^{J} x_{i j k t}}{\sum_{k=1}^{K} \sum_{j=1}^{J} x_{i j k t}} .
$$

In other words, provincial distance elasticity is a double mean of (weighted) sectoral and time coefficients.

${ }^{8}$ The estimate of $B O R D E R$ in Table 4 refers to export sectors and not to provinces. 
Denmark's Greenland). ISTAT is also the source of provincial population and income, the latter measured as the sum of value added in agriculture, industry and service except the public sector and financial services.

Country income and population come from the World Development Indicators 2007 (WDI) of the World Bank. We lose some records in merging the two datasets because of the mismatching between ISTAT export destination and WDI country definition (e.g., Timor-Leste). We lose records because income is not reported for some countries (e.g., Brunei and Cuba). These inevitable trimmings, however, are of little consequence for the final research outcome. Variable $d_{i j}$ is

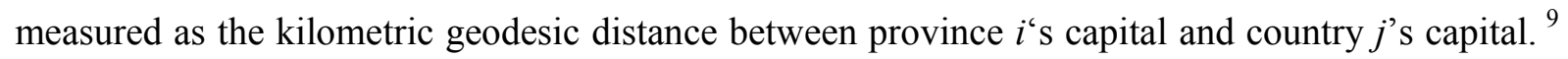
Data on provincial latitude and longitude are provided by the official sites of each province; data on capitals' latitude and longitude are from the World Factbook of the Central Intelligence Agency.

As to institutional factors, we define 11 separate RTAs, with year of entry and exit of each member. ${ }^{10}$ Italy is a member of the European Union and when a province trades with a country that is a member of another RTA, the InterRTA dummy is equal to one. Information on common money, the euro, comes from the European Commission.

Table 1 presents descriptive statistics of our dataset. Average provincial income is $\$ 11.3$ billion (Panel A) vs. an average country income of $\$ 168.3$ billion (Panel B). ${ }^{11} 15.5$ percent of Italian provinces have a common land border with foreign countries. 7.1 percent of provincial trade flows go to members of the European Union, 3.2 percent to countries that share the same currency (the euro), and 28 percent to countries affiliated with other RTAs. Panel C gives descriptive statistics in relation to aggregate provincial exports (top-down dataset) and Panel D in relation to the 21

\footnotetext{
${ }^{9}$ The applied formula is:

$d_{i j}=r \cdot a \cos \left(\sin \left(\frac{\pi \cdot \text { lat }_{i}}{180}\right) \cdot \sin \left(\frac{\pi \cdot \text { lat }_{j}}{180}\right)+\cos \left(\frac{\pi \cdot \text { lat }_{i}}{180}\right) \cdot \cos \left(\frac{\pi \cdot \text { lat }_{j}}{180}\right) \cdot \cos \left(\frac{\pi \cdot \text { lon }_{j}}{180}\right)-\cos \left(\frac{\pi \cdot \text { lon }_{i}}{180}\right)\right)$,
}

where the average earth radius $r$ is $6,371 \mathrm{~km}, \operatorname{acos}(x)$ is the radian value of the arc-cosine of $x, i$ is the province, $j$ is the country, and lat and lon indicate respectively latitude and longitude. The maximum error between real and geodesic distance is less than $20 \mathrm{~km}$.

${ }^{10}$ They are European Union, U.S-IS, NAFTA, CARICOM, PATCRA, ANZCERTA, CACM, MECOSUR, ASEAN, SPARTECA, and ANDEAN; see Oh (2006).

${ }^{11}$ The range from $\$ 1.3$ to $\$ 154.8$ billion for provinces and from $\$ 0.041$ to $\$ 11,711.8$ billion for country income (with respective standard deviations of $\$ 15.8$ and $\$ 812.5$ billion) indicates high income variability. 
provincial export sectors (bottom-up dataset). Average incomes rise in the larger sample size because of the higher frequency of high-income areas, which tend to export more than low-income areas. The same occurs for the number of trade relations among RTA members as a proportion of maximum bilateral relations and for the share of common money countries. The incidence of common border loses relative to other institutional factors. Average distance falls from 5,231 km in Panel C to 4,451 in Panel D suggesting that near countries import more sectors than distant countries. Panel D also reports difference-of-mean and Wilcoxon tests with respect to Panel C that indicate that the top-down and the bottom-up datasets are similar. The Kolmogorv-Smirnov test refutes at the 99 percent confidence level the null hypothesis that the distribution of Panel C differs from that of Panel D, except for border (not reported).

Average provincial exports are $\$ 19.5$ billion in the top-down dataset and $\$ 2.6$ billion in the bottom-up dataset. There is no bias selection because ISTAT reports all export values. Figure 1 shows that provincial exports from the top-down dataset (130,321 observations) have a profile consistent with a log-normal distribution. In the GE the normality of the dependent variable is critical because the estimations are basically OLS. A log-normal distribution also emerges from the bottom-up dataset (972,754 observations); see Figure 2. In sum, normality appears to be robust to data aggregation.

Finally, we report on the zero-values of the bilateral trade flow matrix. Complete specialization models, such as AvW's, imply that this matrix be full. The question is at what level of aggregation one should expect a relatively full matrix. Haveman and Hummels $(2004,211)$ report a 73 percent matrix fullness at the four-digit SITC level. Although our level of disaggregation is much shallower than the four-digit SITC category, we expect more zeros because of territorial disaggregation. ${ }^{12}$ With 972,754 actual observations against a potential number of 4,066,440 observations, our trade matrix has a 24 percent average fullness. Table 2 shows the distribution of fullness by sector. Relative large numbers in the table reflect comparative advantage and diffuse

\footnotetext{
${ }^{12}$ The Italian classification is called ATECO and is very similar to the international ISIC classification.
} 
localization of production. Typical Italian products such as "Machinery and Equipment" and "Textiles and Textile Products" are 6 to 11 times fuller than sectors with low comparative advantage, such as "Coke, Refined Petroleum Products and Nuclear Fuel."

\section{FINDINGS}

\section{$\underline{\text { Top-down model }}$}

Table 3 presents the results of the top-down model. Our panel estimates use a cluster correction for the province-country pair and robust standard errors. The former reduces potential pair serial correlation and the latter corrects for potential heteroschedasticity. We would have also employed the Hausman (1978) specification test to compare fixed with random effects but we could not do it because of the high number of groups $(16,629)$. Instead, we relied on the Breusch and Pagan Lagrange-Multiplier (1979, BPLM for short) test, which rejects the null hypothesis of zero-variance implied by the fixed effect model in favor of the alternative random effect model.

Provincial and country income elasticities have the expected signs and are statistically significant even if they are individually different from one, a result that is in contrast with theory but accords with much of the empirical literature. The $R T A$ semi-elasticity is statistically positive in two out of the three methods but the size is very sensitive to the methodology. ${ }^{13}$ The negative InterRTA semi-elasticity in two out of the three methods suggests trade diversion, but the size, like for the RTA coefficient, is very sensitive to the chosen methodology. The MONEY semi-elasticity is statistically positive but of low economic impact. ${ }^{14}$ The BORDER semi-elasticity is statistically positive, stable through the different methods, and economically relevant. ${ }^{15}$ The 103 distance elasticities interacting with provinces are all negative and statistically very significant, individually

\footnotetext{
${ }^{13}$ We recall that method (a) uses country fixed effects, method (b) country pair random effects, and method (c) country fixed effects and country pair random effects. All methods use year dummies.

${ }^{14}$ For example, the exponent of 0.061 (the estimated MONEY coefficient under method (c)) is 1.06, suggesting that common money raises exports by 6 percent. The effects of common money on trade reported by Rose (2000), Rose and van Wincoop (2001), and Frankel and Rose (2002) are much higher. There is a considerable controversy on this subject.

${ }^{15}$ For example, the exponent of 0.507 (the estimated BORDER coefficient under method (c)) means that a common border raises exports by 66 percent.
} 
as well as jointly. The average distance elasticity is -1.268 under method (a), -1.037 under method (b), and -1.388 under method (c). Variability across provinces is high, ranging from a minimum of -1.738 for Cosenza, in the South, under method (c) to a maximum of -0.840 for Vercelli, in the North, under method (b). Clearly, there is more than transportation in distance. Finally, the regressions explain a great portion of the export variance and confirm the empirical robustness of the GE also at a highly disaggregated level.

The impact of TCs on exports is the sum of distance, BORDER, RTA, InterRTA, and $M O N E Y$ elasticities, with the last three being common to all Italian provinces. In our model, this impact for, say, Vercelli, using method (b), is the sum of its own distance elasticity, -0.840 , its own BORDER elasticity, 0.0008 , and the three common (to all provinces) elasticities that add up to 0.0565; that is, -0.7828 . For Cosenza, TC elasticity, using method (c), is the sum of its own distance elasticity, -1.738 , plus the three common elasticities that add up to -0.2163 ; that is, $-1.9543 .{ }^{16}$ Naturally, in comparing provinces, the common TCs drop out and one is left with the sum of distance and border elasticities. Distance elasticity accounts, on average, for about 99 percent of province-specific TCs.

To test our main hypothesis, we regress mean-adjusted provincial TC elasticities on average provincial per-capita income. We report scatter plots, in the $\left[\beta_{S, i}-\bar{\beta}_{S, i}, Y_{i} / N_{i}\right]$ space, and fitted lines for each of the three methods in the top part of Figure 3; estimation results are shown in Table 5. The fitted lines are positive and statistically very significant: provinces with lower (i.e., more negative) than average TC elasticities, such as Cosenza, are associated with lower per-capita income, while provinces with higher (i.e., less negative) than average TC elasticities, such as Vercelli, are associated with higher per-capita income. ${ }^{17}$ In essence, developing provinces face higher TCs than developed provinces.

\section{$\underline{\text { Bottom-up model }}$}

\footnotetext{
${ }^{16}$ For Cosenza, BORDER is zero and the RTA coefficient is not statistically different from zero.

${ }^{17}$ While the slope coefficients of the graphs appear low (ranging from 0.0194 to 0.0223 ), it should be remembered that we correlate a pure number like elasticity with a level variable like per-capita income.
} 
We move now to the bottom-up model to see whether we can mimic provincial TC elasticities. Table 4 presents results of sector regressions; cf. equation (5). We recall that provincial TC elasticities are the sum of provincial distance elasticities, obtained by aggregating sectoral distance elasticities, and provincial border elasticities obtained from the top-down model.

The number of observations rises dramatically to 972,754 , making it computationally impossible to estimate the model under method (c). To get some results, we trim the dataset eliminating export values below $\$ 100,000$ and reduce the number of observations to 462,211 under method (c). Again, we cannot perform the Hausman specification test and rely on BPLM to select method (b) as our best. Income elasticity is not statistically different from one for Italian provinces under methods (a) and (b) but is different from one for countries. TC variables show up statistically significant. The RTA semi-elasticity suggests that the European Union has been a hindrance to trade for its members. We do not hold much credence to this result that we attribute to country fixed or pair random effects that absorb a great deal of the RTA effects. The InterRTA semi-elasticity is negative under method (a) and positive under method (b); again, we suspect that country fixed or pair random effects are driving these changes. The MONEY semi-elasticity is positive, economically small, and relatively stable across methods. The BORDER semi-elasticity rises from method (a) to method (b) and then falls again under method (c). All 21 sector distance elasticities are negative and very statistically significant, individually as well as jointly. Their variability is higher than provincial distance elasticities, as one would expect: the range is from a minimum of -2.39 of “Coal, Lignite, Peat, etc." under method (a), to a maximum of -0.47 for "Machinery, etc." under method (b). The explained variance of the regressions is lower than in Table 3.

To test our main hypothesis, we proceed exactly as in the top-down model. The bottom portion of Figure 3 shows the scatter plots and the fitted lines of the relationship between meanadjusted provincial TC elasticities and provincial per-capita income. Qualitatively, we confirm what we obtained in the top-down model. However, the top-down model provides a tighter fit than the bottom-up model, as evidenced by the smaller values of the slopes of the latter. Clearly, something 
is missing in provincial TC elasticities from the bottom-up model: a sort of residual agglomeration factor that can be thought of as the equivalent of total productivity factor in neoclassical production functions. Agglomeration externalities, level and quality of the infrastructure and quality of publicsector services are potential candidates to explain this residual agglomeration factor.

We conducted two exercises to check on the robustness of the bottom-up results. ${ }^{18}$ The first was to estimate equation (5) with sectoral data at the national level. In the presence of an aggregation problem we would expect a closer convergence between the estimates of the top-down model and the bottom-up model with national level data. The small improvement we find relative to the provincial bottom-up model suggests an aggregation problem that goes beyond the simple sum of provincial sectoral effects. The second was to repeat the analysis with unconstrained control variables: that is, estimating $K$ regressions so as to allow the control variables to have different effects on the $K$ sectors. This should be more realistic because the GE is an expenditure function and income elasticities are likely to differ across different goods. We conducted the second exercise at national and provincial level using the three methods. In brief, methods (a) and (b) applied to national data corroborate our hypothesis. On the other hand, random pair effects provide an excessively detailed specification with unconstrained control variables, and disaggregation affects negatively the estimation with provincial data. Some sectors generate inconsistent estimates because of the low number of observations and few provincial distance elasticities emerge as outliers. It is worth noting that the presence of outliers may work against our hypothesis; see Figure 3.

In sum, we have marshalled a broad body of evidence in support of our hypothesis that TCs and economic development are inversely related in Italy. Development patterns appear to be consistent with the main implications of agglomeration theory: developed and richer provinces occur more frequently in the industrial North than in the still developing South. These patterns are shown visually in Figure 4, where Italian provinces are coded according to the values of the estimated provincial TC elasticities from the top-down model. With few exceptions, provinces in the "First

\footnotetext{
${ }^{18}$ Results are not reported for brevity but are available upon request.
} 
Italy" (North-West) and "Third Italy" (North-East and parts of the Center) face lower TCs than provinces in the developing South; these results are consistent with the message of the literature on heterogeneous regional economic development.

\section{CONCLUSIONS}

The key result of the paper is that economic development is associated with lower trade costs. Using different methods to control for multilateral resistance, we apply two alternative forms of a gravity equation, a top-down version and a bottom-up version, to exports from 103 Italian provinces to 188 countries over the period $1995-2004$. Under both alternatives we fail to reject our hypothesis that trade costs are inversely related to economic development. We find, however, that the slope of provincial TC elasticities -our measure of provincial heterogeneity- with respect to provincial percapita income has the same sign in both models but the steepness is higher in the top-down model. Three possible reasons come to mind for this outcome. The first is that a country's income is a good proxy of its aggregate expenditures but not of individual sectors' expenditures, which have a higher variability than aggregate expenditures. The second has to do with an aggregation problem. Anderson and van Wincoop (2004) show that the absolute effect of trade barriers on aggregate trade is larger when barriers fall than when barriers rise because trade costs are decreasing and convex in their components. Provincial TC elasticities from sectoral distance elasticities fail to capture this effect. Some evidence of this emerges from the fact that the slopes get steeper as we move from provincial to national level export data. The last has already been mentioned, namely the possible presence of an agglomeration residual factor equivalent to total factor productivity in neoclassical production functions. It may be tempting to surmise that the main sources of such a residual are differences in agglomeration externalities, in level and quality of infrastructure and in the quality of public-sector services. Clearly, this issue needs further study.

We have measured the impact of trade costs on exports as the sum of two province-specific elasticities, distance and border, and three other elasticities $-R T A$, InterRTA, and $M O N E Y$ - that are 
common to all Italian provinces. We plan, in the future, to inquire for possible asymmetric effects of these "common" trade costs, the conjecture being that the effects of the European Union and of the euro are felt differently across Italian provinces.

\section{References}

Anderson, J.E. (1979) A theoretical foundation for the gravity equation. American Economic Review, 69: 106-16.

Anderson, J.E., van Wincoop, E. (2003) Gravity with gravitas: a solution to the border puzzle. American Economic Review, 93(1): 170-192.

Anderson, J.E., van Wincoop, E. (2004) Trade costs. Journal of Economic Literature, 42(3): 691-751.

Bagnasco, A. (1977) Tre Italie: la problematica territoriale dello sviluppo italiano. Bologna: Il Mulino.

Baier, S.L., Bergstrand, J.H. (2006) Bonus vetus OLS: A simple approach for addressing the 'border puzzle' and other gravity-equation issues, unpublished typescript.

Baldwin, R., Taglioni, D. (2006) Gravity for Dummies and Dummies for Gravity Equations, NBER Working Paper 12516, http://www.nber.org/papers/w12516.

Becattini, G. (1990) The Marshallian industrial district as a socio-economic notion. In F. Pyke, G. Becattini and W. Sengenberger (eds.) Industrial districts and inter-firm co-operation in Italy, Geneva, International Institute for Labour Studies, 52-74.

Becattini, G. (2007) Il calabrone Italia. Bologna: Il Mulino.

Bergstrand, J.H. (1985) The gravity equation in international trade: some microeconomic foundations and empirical evidence. The Review of Economics and Statistics, 67(3): 474-481.

Bergstrand, J.H. (1989) The generalized gravity equation, monopolistic competition, and the factorproportions theory in international trade. The Review of Economics and Statistics, 71(1): 143-153.

Braudel, F. (1992) Civilization \& capitalism, 15 th $-18^{\text {th }}$ Century, vol. 3: The Perspective of the World. Berkeley: University of California Press.

Breusch, T., Pagan, A. (1979) A simple test of heteroskedasticity and random coefficient variation. Econometrica, 47: 1287-1294.

Brusco, S. (1990) The idea of the industrial district: Its genesis. In F. Pyke, G. Becattini and W. Sengenberger (eds.) Industrial districts and inter-firm co-operation in Italy, Geneva, International Institute for Labour Studies, 10-19.

Carrère, C. (2006) Revisiting the effects of regional trade agreements on trade flows with proper specification of the gravity model. European Economic Review, 50: 223-247.

Chen, N. (2004) Intra-national versus international trade in the European Union: why do national borders matter? Journal of International Economics, 63: 93-118.

Cheng, I.H., Wall, H.J. (2003) Controlling for heterogeneity in gravity models of trade and integration. Federal Reserve Bank of St. Louis Working Paper 1999-010D.

Deardorff, A.V. (1998) Determinants of bilateral trade: Does gravity work in a neoclassical world? In J. A. Frankel (ed.). The Regionalization of the World Economy. Chicago: University of Chicago Press.

Feenstra, R. (2003) Advanced international trade. Princeton, N.J.: Princeton University Press. 
Frankel, J., Rose, A. (2002) An estimate of the effect of common currencies on trade and income. Quarterly Journal of Economics, 117: 437-466.

Fratianni, M., Kang, H. (2006) Heterogeneous distance-elasticities in trade gravity models, Economics Letters, 90(1): 68-71.

Gould, D. (1994) "Immigrant links to the home country: Empirical implications for U.S. bilateral trade flows. Review of Economics and Statistics, 69:301-316.

Hausman, J.A. (1978) Specification tests in econometrics. Econometrica, 46(6): 1251-1271.

Haveman, J., Hummels, D. (2004) Alternative hypotheses and the volume of trade: the gravity equation and the extent of specialization. Canadian Journal of Economics, 37(1): 199-218.

Head, K., Ries, J. (1998) Immigration and trade creation: Econometric evidence from Canada. Canadian Journal of Economics, 31:46-62.

Helliwell, J.F. (1998) How much do national borders matter? Washington, D.C.: The Brookings Institution.

Helliwell, J.F. (1999) Language and trade. In A. Breton(ed.) Exploring the economics of language, Ottawa, Department of Heritage, 26.

Helpman, E. (1987) Imperfect competition and international trade: Evidence from fourteen industrial countries. Journal of the Japanese and International Economies, 1: 62-81.

Hummels, D. (2007) Transportation costs and international trade in the second era of globalization. Journal of Economic Perspectives, 21(3): 131-154.

Hummels, D., Ishii, J., Yi, K.M. (2001) The nature and growth of vertical specialization in world trade, Journal of International Economics, 54: 75-96.

Hutchinson, W. (2002) Does ease of communication increase trade? Commonality of language and bilateral trade. Scottish Journal of Political Economy, 49: 544-556.

Kang, H., Fratianni, M. (2006) International trade, OECD membership, and religion. Open Economies Review, 17 (4-5): 493-508.

Kindleberger, C.P. (1996) World economic primacy: 1500 to 1900. Oxford: Oxford University Press.

Kuznets, S. (1966) Modern economic growth: Rate, structure and spread. New Haven, CT: Yale University Press.

Krugman, P. (1991) Increasing returns and economic geography. Journal of Political Economy, 99(3): 483499.

Lutz, V. (1962) Italy. A study in economic development. Oxford: Oxford University Press.

Markusen, A. (1996) Sticky places in slippery spaces: A typology of industrial districts. Economic Geography, 72(3): 293-313.

Martin, P., Ottaviano, G.I.P. (2001) Growth and agglomeration. International Economic Review, 42(4): 947968.

Martin, R., Sunley, P. (1996) Paul Krugman's geographical economics and its implications for regional development theory: A critical Assessment. Economic Geography, 72(3): 259-292.

McCallum, J., (1995) National borders matter: Canada-US regional trade patterns. American Economic Review, 85(3): 615-623.

Obstfeld, M., Rogoff, K. (2000) The six major puzzles in international macroeconomics: Is there a common cause? In B. Bernanke and K. Rogoff (eds.). NBER Macroeconomics Annual 2000: 339-390. Cambridge, MA: MIT Press.

Oh, C.H. (2006) Technical appendix on the regional economic integration database. In M. Fratianni (ed.) Regional Economic Integration. Amsterdam, Elsevier JAI.

Rauch, J.E. (1999) Networks versus markets in international trade. Journal of International Economics, 48:7-35. 
Rauch, J.E., Trindade, V. (2001) Ethnic Chinese networks in international trade. Review of Economics and Statistics, 84: 116-130.

Rose, A.K. (2000) One money, one market: the effect of currency unions on trade. Economic Policy, 30: 746.

Rose, A.K., van Wincoop, E. (2001) National money as a barrier to trade: The real case for monetary union. American Economic Review, 91(2): 386-390.

Venables, A.J. (1996) Equilibrium locations of vertically linked industries. International Economic Review, 37: $341-59$.

Venables, A.J. (2005) Spatial disparities in developing countries: cities, regions, and international trade. Journal of Economic Geography, 5: 3-21. 
Table 1: Descriptive Statistics (millions of US dollars for Exports, $Y_{i}$ and $Y_{j}$ )

\begin{tabular}{|c|c|c|c|c|c|c|c|}
\hline & Mean & (a) & Median & (b) & Stand.Dev. & Min & $\operatorname{Max}$ \\
\hline \multicolumn{8}{|l|}{$\begin{array}{l}\text { Panel A } \\
(\mathrm{N}=103)\end{array}$} \\
\hline$Y_{i}$ & $11,315.7$ & & $6,967.2$ & & $15,809.2$ & $1,284.0$ & $154,822.0$ \\
\hline Border & 0.155 & & 0 & & 0.362 & 0 & 1 \\
\hline \multicolumn{8}{|l|}{$\begin{array}{l}\text { Panel B } \\
(\mathrm{N}=188)\end{array}$} \\
\hline$Y_{j}$ & $168,332.7$ & & $8,089.5$ & & $812,480.3$ & 40.8 & $11,711,833.7$ \\
\hline RTA & 0.071 & & 0 & & 0.257 & 0 & 1 \\
\hline Inter-RTA & 0.280 & & 0 & & 0.449 & 0 & 1 \\
\hline MONEY & 0.032 & & 0 & & 0.176 & 0 & 1 \\
\hline BORDER & 0.022 & & 0 & & 0.147 & 0 & 1 \\
\hline \multicolumn{8}{|c|}{$\begin{array}{l}\text { Panel C } \\
(\mathrm{N}=130,321)\end{array}$} \\
\hline Exports & 19.5 & & 0.7 & & 108.9 & $3 \times 10^{-6}$ & $5,238.2$ \\
\hline$Y_{i}$ & $13,135.2$ & & 7,848.3 & & $17,968,2$ & $1,284.0$ & $154,821.9$ \\
\hline$Y_{j}$ & $238,517.9$ & & $18,672.6$ & & $965,930.3$ & 40.8 & $11,711,833.7$ \\
\hline Distance & 5,231 & & 4,444 & & 3,862 & 69 & 18,932 \\
\hline RTA & 0.104 & & 0 & & 0.305 & 0 & 1 \\
\hline Inter-RTA & 0.232 & & 0 & & 0.422 & 0 & 1 \\
\hline MONEY & 0.050 & & 0 & & 0.218 & 0 & 1 \\
\hline BORDER & 0.001 & & 0 & & 0.036 & 0 & 1 \\
\hline \multicolumn{8}{|c|}{$\begin{array}{l}\text { Panel D } \\
(\mathrm{N}=972,754)\end{array}$} \\
\hline Exports $^{\mathrm{c}}$ & 2.6 & *** & 0.1 & $* \star \star$ & 18.1 & $1 \times 10^{-6}$ & $1,531.7$ \\
\hline$Y_{i}^{c}$ & $16,434.0$ & $\star * \star *$ & $9,198.2$ & $\star * \star *$ & $22,235.2$ & $1, .284 .0$ & $154,821.9$ \\
\hline$Y_{j}^{c}$ & $417,360.6$ & 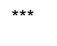 & $60,817.2$ & $\star * \star$ & $1,320,683.7$ & 40.8 & $11,711,833.7$ \\
\hline Distance $^{c}$ & 4.451 & ${ }^{* * *}$ & 2,641 & $* *$ & 3,962 & 69 & 18,932 \\
\hline RTA & 0.183 & $\star \star \star ~$ & 0 & 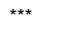 & 0.387 & 0 & 1 \\
\hline Inter-RTA & 0.203 & 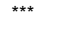 & 0 & $* \star *$ & 0.402 & 0 & 1 \\
\hline MONEY & 0.089 & 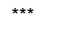 & 0 & $\star * \star \star$ & 0.285 & 0 & 1 \\
\hline BORDER & 0.003 & *** & 0 & $\star \star \star ~$ & 0.057 & 0 & 1 \\
\hline
\end{tabular}


Figure 1: Export distribution: aggregated data

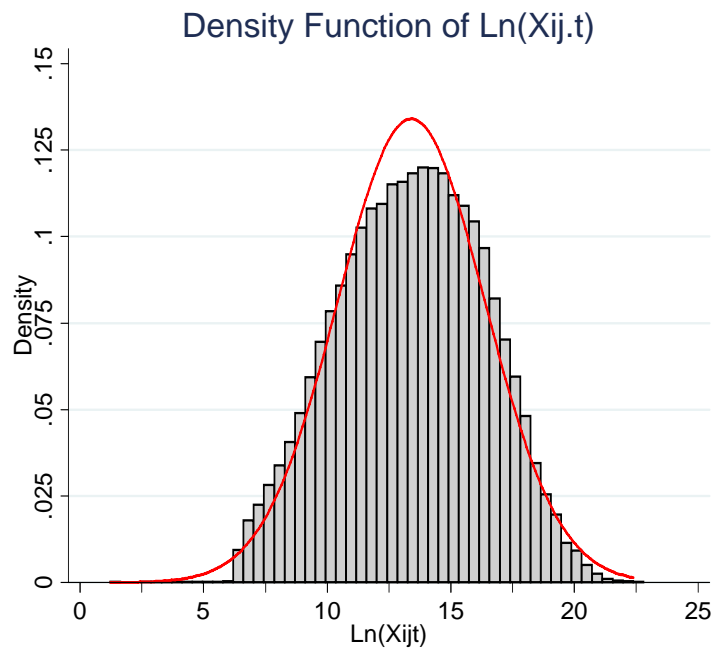

Note: 130,321 observations. $\mathrm{I}=103, \mathrm{~J}=188, \mathrm{~K}=1, \mathrm{~T}=10$.
Figure 2: Export distribution: detailed data

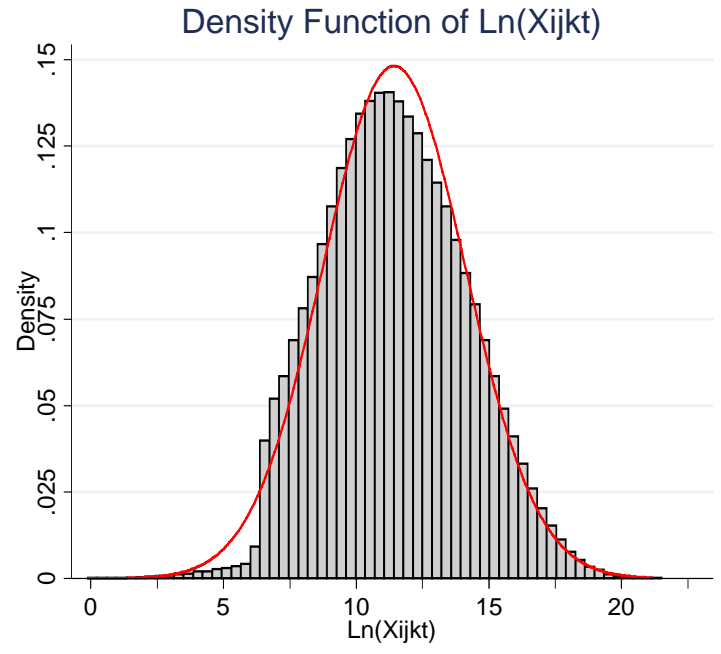

Note: 972,754 observations. $\mathrm{I}=103, \mathrm{~J}=188, \mathrm{~K}=21, \mathrm{~T}=10$.

Table 2: Full cells in the trade matrix

\begin{tabular}{|c|c|}
\hline Sector & $\frac{\text { FullCell }_{i, j, t}}{\text { TotalCell }_{i, j, t}}$ \\
\hline Agriculture, Hunting, Forestry & 0.31505371 \\
\hline Fish, Fishing Products & 0.07920884 \\
\hline Coal, Lignite, Peat, Crude Petroleum, Natural Gas, Uranium, Thorium & 0.03672795 \\
\hline Metal Ores, Other Mining, Quarrying Products & 0.15978620 \\
\hline Food Products, Beverages, Tobacco & 0.39478414 \\
\hline Textiles, Textile Products & 0.41405701 \\
\hline Leather, Leather Products & 0.30810783 \\
\hline Wood, Products of Wood, Cork (Except Furniture), Articles of Straw, Plaiting Materials & 0.27897129 \\
\hline Pulp, Paper, Paper Products, Recorded Media, Printing Services & 0.29880706 \\
\hline Coke, Refined Petroleum Products, Nuclear Fuel & 0.09446395 \\
\hline Chemicals, Chemical Products, Man-Made Fibres & 0.39609068 \\
\hline Rubber, Plastic Products & 0.37533051 \\
\hline Other Non Metallic Mineral Products & 0.37696757 \\
\hline Basic Metals, Fabricated Metal Products & 0.42533051 \\
\hline Machinery and Equipment N.E.C. & 0.51390725 \\
\hline Electrical and Optical Equipment & 0.42727742 \\
\hline Transport Equipment & 0.35043379 \\
\hline Other Manufactured Goods N.E.C. & 0.39884321 \\
\hline Electrical Energy, Gas, Steam, Water & 0.00343937 \\
\hline Real Estate, Renting, Business Services & 0.08559182 \\
\hline Other Community, Social and Personal Services & 0.06893720 \\
\hline
\end{tabular}


Table 3: Top-Down Model: Step 1 - Physical Distance interacting with Provinces. Period 1995-2004 (N=130,321)

\begin{tabular}{|c|c|c|c|c|c|c|c|}
\hline COEFFICIENT & (a) & (b) & (c) & COEFFICIENT & (a) & (b) & (c) \\
\hline Year Dummies & Yes & Yes & Yes & $\mathrm{d}^{*}$ Massa-Carrara & -1.082 & -0.877 & -1.214 \\
\hline Constant & -29.29 & -31.79 & -28.97 & $d^{*}$ Matera & -1.310 & -1.068 & -1.424 \\
\hline $\ln \left(Y_{i}\right)$ & 1.465 & 1.364 & 1.457 & $d^{*}$ Messina & -1.521 & -1.256 & -1.621 \\
\hline $\ln \left(Y_{j}\right)$ & 0.785 & 0.929 & 0.831 & d*Milano & -1.235 & -0.990 & -1.368 \\
\hline BORDER & 0.583 & 0.760 & 0.507 & $\mathrm{~d}^{*}$ Modena & -1.093 & -0.875 & -1.229 \\
\hline RTA & 1.083 & 0.166 & -1.219 & d*Napoli & -1.312 & -1.077 & -1.442 \\
\hline inter-RTA & -0.480 & 0.155 & -0.399 & $\mathrm{~d}$ *Novara & -1.128 & -0.918 & -1.263 \\
\hline MONEY & 0.061 & 0.065 & 0.061 & d*Nuoro & -1.567 & -1.297 & -1.660 \\
\hline $\mathrm{d}^{*}$ Agrigento & -1.628 & -1.370 & -1.731 & $d *$ Oristano & -1.510 & -1.204 & -1.569 \\
\hline $\mathrm{d}^{*}$ Alessandria & -1.148 & -0.936 & -1.281 & d*Padova & -1.158 & -0.937 & -1.291 \\
\hline $\mathrm{d}^{*}$ Ancona & -1.147 & -0.940 & -1.287 & d*Palermo & -1.541 & -1.280 & -1.643 \\
\hline $\mathrm{d}^{*}$ Aosta & -1.327 & -1.095 & -1.440 & d*Parma & -1.121 & -0.910 & -1.256 \\
\hline $\mathrm{d}^{*}$ Arezzo & -1.142 & -0.930 & -1.274 & d*Pavia & -1.153 & -0.939 & -1.286 \\
\hline$d^{*}$ Ascoli-Piceno & -1.179 & -0.969 & -1.316 & $\mathrm{~d}^{*}$ Perugia & -1.279 & -1.058 & -1.408 \\
\hline $\mathrm{d}^{*}$ Asti & -1.175 & -0.957 & -1.297 & $\mathrm{~d}^{*}$ Pesaro & -1.146 & -0.929 & -1.275 \\
\hline$d^{*}$ Avellino & -1.296 & -1.063 & -1.411 & d*Pescara & -1.275 & -1.053 & -1.398 \\
\hline $\mathrm{d} *$ Bari & -1.366 & -1.135 & -1.494 & $d *$ Piacenza & -1.117 & -0.907 & -1.248 \\
\hline$d *$ Belluno & -1.135 & -0.931 & -1.275 & $d *$ Pisa & -1.183 & -0.965 & -1.312 \\
\hline$d *$ Benevento & -1.547 & -1.258 & -1.621 & $\mathrm{~d}$ *Pistoia & -1.132 & -0.922 & -1.261 \\
\hline$d *$ Bergamo & -1.167 & -0.948 & -1.306 & $d *$ Pordenone & -1.098 & -0.886 & -1.230 \\
\hline $\mathrm{d}^{*}$ Biella & -1.159 & -0.956 & -1.296 & $\mathrm{~d} *$ Potenza & -1.390 & -1.151 & -1.504 \\
\hline$d^{*}$ Bologna & -1.164 & -0.939 & -1.296 & d*Prato & -1.076 & -0.876 & -1.218 \\
\hline d*Bolzano & -1.404 & -1.175 & -1.529 & d*Ragusa & -1.522 & -1.269 & -1.629 \\
\hline $\mathrm{d}^{*}$ Brescia & -1.207 & -0.987 & -1.345 & $\mathrm{~d}^{*}$ Ravenna & -1.159 & -0.950 & -1.294 \\
\hline d*Brindisi & -1.355 & -1.109 & -1.464 & d*Reggio-Calabria & -1.551 & -1.293 & -1.648 \\
\hline $\mathrm{d}^{*}$ Cagliari & -1.373 & -1.126 & -1.492 & d*Reggio-Emilia & -1.077 & -0.860 & -1.210 \\
\hline $\mathrm{d}^{*}$ Caltanisetta & -1.444 & -1.185 & -1.545 & $\mathrm{~d}^{*}$ Rieti & -1.271 & -1.016 & -1.361 \\
\hline $\mathrm{d}^{*}$ Campobasso & -1.341 & -1.101 & -1.449 & d*Rimini & -1.236 & -1.017 & -1.363 \\
\hline $\mathrm{d}^{*}$ Caserta & -1.292 & -1.063 & -1.415 & d*Roma & -1.427 & -1.181 & -1.555 \\
\hline $\mathrm{d}^{*}$ Catania & -1.463 & -1.217 & -1.574 & $\mathrm{~d}^{*}$ Rovigo & -1.193 & -0.968 & -1.312 \\
\hline $\mathrm{d} *$ Catanzaro & -1.595 & -1.311 & -1.672 & $d *$ Salerno & -1.222 & -0.998 & -1.352 \\
\hline $\mathrm{d}^{*}$ Chieti & -1.201 & -0.977 & -1.324 & $d^{*}$ Sassari & -1.478 & -1.239 & -1.596 \\
\hline d*Como & -1.136 & -0.921 & -1.271 & $d^{*}$ Savona & -1.284 & -1.046 & -1.397 \\
\hline$d^{*}$ Cosenza & -1.647 & -1.373 & -1.738 & $d *$ Siena & -1.131 & -0.914 & -1.254 \\
\hline $\mathrm{d}^{*}$ Cremona & -1.186 & -0.972 & -1.319 & $d^{*}$ Siracusa & -1.189 & -0.952 & -1.305 \\
\hline $\mathrm{d}^{*}$ Crotone & -1.477 & -1.218 & -1.569 & d*Sondrio & -1.269 & -1.036 & -1.386 \\
\hline d*Cuneo & -1.177 & -0.959 & -1.309 & $\mathrm{~d} *$ Taranto & -1.365 & -1.123 & -1.485 \\
\hline d*Enna & -1.525 & -1.257 & -1.617 & $d^{*}$ Teramo & -1.164 & -0.951 & -1.293 \\
\hline d*Ferrara & -1.182 & -0.965 & -1.311 & d*Terni & -1.217 & -0.994 & -1.338 \\
\hline$d *$ Firenze & -1.222 & -1.000 & -1.356 & $\mathrm{~d}^{*}$ Torino & -1.277 & -1.049 & -1.415 \\
\hline d*Foggia & -1.533 & -1.272 & -1.630 & $d^{*}$ Trapani & -1.416 & -1.168 & -1.522 \\
\hline d*Forlì & -1.160 & -0.946 & -1.293 & d*Trento & -1.277 & -1.059 & -1.409 \\
\hline$d^{*}$ Frosinone & -1.240 & -1.009 & -1.357 & d*Treviso & -1.139 & -0.915 & -1.271 \\
\hline $\mathrm{d}^{*}$ Genova & -1.251 & -1.025 & -1.382 & $\mathrm{~d}^{*}$ Trieste & -1.204 & -0.978 & -1.326 \\
\hline $\mathrm{d}^{*}$ Gorizia & -1.148 & -0.930 & -1.271 & d*Udine & -1.196 & -0.984 & -1.335 \\
\hline $\mathrm{d}^{*}$ Grosseto & -1.348 & -1.093 & -1.443 & $d^{*}$ Varese & -1.132 & -0.910 & -1.264 \\
\hline d*Imperia & -1.352 & -1.119 & -1.468 & $d *$ Venezia & -1.229 & -1.008 & -1.363 \\
\hline $\mathrm{d}^{*}$ Isernia & -1.121 & -0.906 & -1.250 & $d^{*}$ Verbania & -1.280 & -1.062 & -1.406 \\
\hline d*LaSpezia & -1.220 & -0.997 & -1.339 & $\mathrm{~d}^{*}$ Vercelli & -1.051 & -0.840 & -1.177 \\
\hline d*L'Aquila & -1.319 & -1.082 & -1.433 & $\mathrm{~d}^{*}$ Verona & -1.176 & -0.953 & -1.307 \\
\hline $\mathrm{d}^{*}$ Latina & -1.194 & -0.973 & -1.324 & $d^{*}$ Vibo-Valentia & -1.488 & -1.199 & -1.550 \\
\hline$d *$ Lecce & -1.386 & -1.149 & -1.502 & $d^{*}$ Vicenza & -1.133 & -0.910 & -1.266 \\
\hline$d *$ Lecco & -1.160 & -0.950 & -1.294 & d*Viterbo & -1.289 & -1.054 & -1.400 \\
\hline d*Livorno & -1.235 & -1.005 & -1.354 & Observations & 130,321 & 130,321 & 130,321 \\
\hline d*Lodi & -1.222 & -1.000 & -1.345 & Number of pair & & 16,629 & 16,629 \\
\hline d*Lucca & -1.135 & -0.912 & -1.258 & $\mathrm{R}^{2}$ & 0.776 & 0.724 & 0.774 \\
\hline$d *$ Macerata & -1.167 & -0.963 & -1.307 & F-test & 480.4 & 76,148 & 129,281 \\
\hline d*Mantova & -1.130 & -0.917 & -1.264 & Prob $>F$ & 0 & 0 & 0 \\
\hline
\end{tabular}

NOTE: Robust standard errors: no-asterisk $\mathrm{p}<0.01 ;^{*} \mathrm{p}<0.05 ;{ }^{* *} \mathrm{p}<0.1 ; * * \mathrm{p}>0.1$. Cluster correction on pairs. See text for (a), (b), (c) methods. 
Table 4: Bottom-Up Model: Step 1 - Physical Distance interacting with Sectors. Period 1995-2004

\begin{tabular}{|c|c|c|c|}
\hline \multirow[b]{2}{*}{ COEFFICIENT } & \multicolumn{3}{|c|}{ Provincial Level } \\
\hline & (a) & (b) & (c) ${ }^{\square}$ \\
\hline Year Dummies & Yes & Yes & Yes \\
\hline Constant & -13.45 & -17.53 & $-0.315^{* * *}$ \\
\hline $\ln \left(Y_{i}\right)$ & 1.051 & 0.903 & 0.46 \\
\hline $\ln \left(Y_{j}\right)$ & 0.627 & 0.536 & 0.442 \\
\hline BORDER & $0.344 * *$ & 1.505 & 0.497 \\
\hline RTA & -2.303 & $-0.056^{* * *}$ & -2.657 \\
\hline inter-RTA & -0.42 & 0.123 & $-0.047 * * *$ \\
\hline MONEY & 0.108 & 0.082 & 0.0566 \\
\hline $\mathrm{d}^{*}$ Agriculture, Hunting, Forestry & -1.821 & -0.802 & -0.91 \\
\hline d*Fish, Fishing Products & -2.198 & -1.203 & -1.047 \\
\hline $\mathrm{d}^{*}$ Coal, Lignite, Peat, Crude Petroleum, Natural Gas, Uranium, Thorium & -2.39 & -1.43 & -0.933 \\
\hline$d *$ Metal Ores, Other Mining, Quarrying Products & -1.978 & -0.979 & -1.014 \\
\hline d*Food Products, Beverages, Tobacco & -1.648 & -0.621 & -0.817 \\
\hline d*Textiles, Textile Products & -1.629 & -0.604 & -0.769 \\
\hline d*Leather, Leather Products & -1.715 & -0.7 & -0.824 \\
\hline $\mathrm{d}^{*}$ Wood, Products of Wood, Cork (Except Furniture), Articles of Straw, Plaiting Materials & -1.905 & -0.901 & -0.99 \\
\hline d*Pulp. Paper, Paper Products, Recorded Media, Printing Services & -1.792 & -0.78 & -0.902 \\
\hline$d *$ Coke, Refined Petroleum Products, Nuclear Fuel & -1.98 & -0.998 & -0.828 \\
\hline$d *$ Chemicals, Chemical Products, Man-Made Fibres & -1.602 & -0.579 & -0.787 \\
\hline d*Rubber, Plastic Products & -1.687 & -0.667 & -0.857 \\
\hline $\mathrm{d}^{*}$ Other Non Metallic Mineral Products & -1.691 & -0.671 & -0.856 \\
\hline d*Basic Metals, Fabricated Metal Products & -1.616 & -0.593 & -0.79 \\
\hline d*Machinery and Equipment N.E.C. & -1.495 & -0.467 & -0.697 \\
\hline d*Electrical and Optical Equipment & -1.633 & -0.608 & -0.793 \\
\hline $\mathrm{d}^{*}$ Transport Equipment & -1.677 & -0.658 & -0.804 \\
\hline $\mathrm{d} *$ Other Manufactured Goods N.E.C. & -1.663 & -0.641 & -0.82 \\
\hline d*Electrical Energy, Gas, Steam, Water & -2.234 & -1.258 & -1.016 \\
\hline d*Real Estate, Renting, Business Services & -2.227 & -1.254 & -1.204 \\
\hline $\mathrm{d}^{*}$ Other Community, Social and Personal Services & -2.167 & -1.174 & -1.122 \\
\hline Observations & 972,754 & 972,754 & 462,211 \\
\hline Number of pair & & 16,629 & 12,495 \\
\hline $\mathrm{R}^{2}$ & 0.387 & 0.352 & 0.366 \\
\hline F-test & 242.5 & 49,406 & 20,467 \\
\hline Prob $>F$ & 0 & 0 & 0 \\
\hline BPLM-Test & & $1,793,846$ & 509,744 \\
\hline Prob $>$ chi 2 & & 0 & 0 \\
\hline
\end{tabular}

NOTE: Robust standard errors in parentheses: no-asterisk $\mathrm{p}<0.01 ;{ }^{*} \mathrm{p}<0.05 ;{ }^{* *} \mathrm{p}<0.1 ;{ }^{* * *} \mathrm{p}>0.1$. Cluster correction on pairs. See text for (a), (b), (c) methods. ${ }^{\square}$ Exports over 100,000 US $\$$ for technical reasons. 
Figure 3: Relative distance elasticity and per capita provincial income
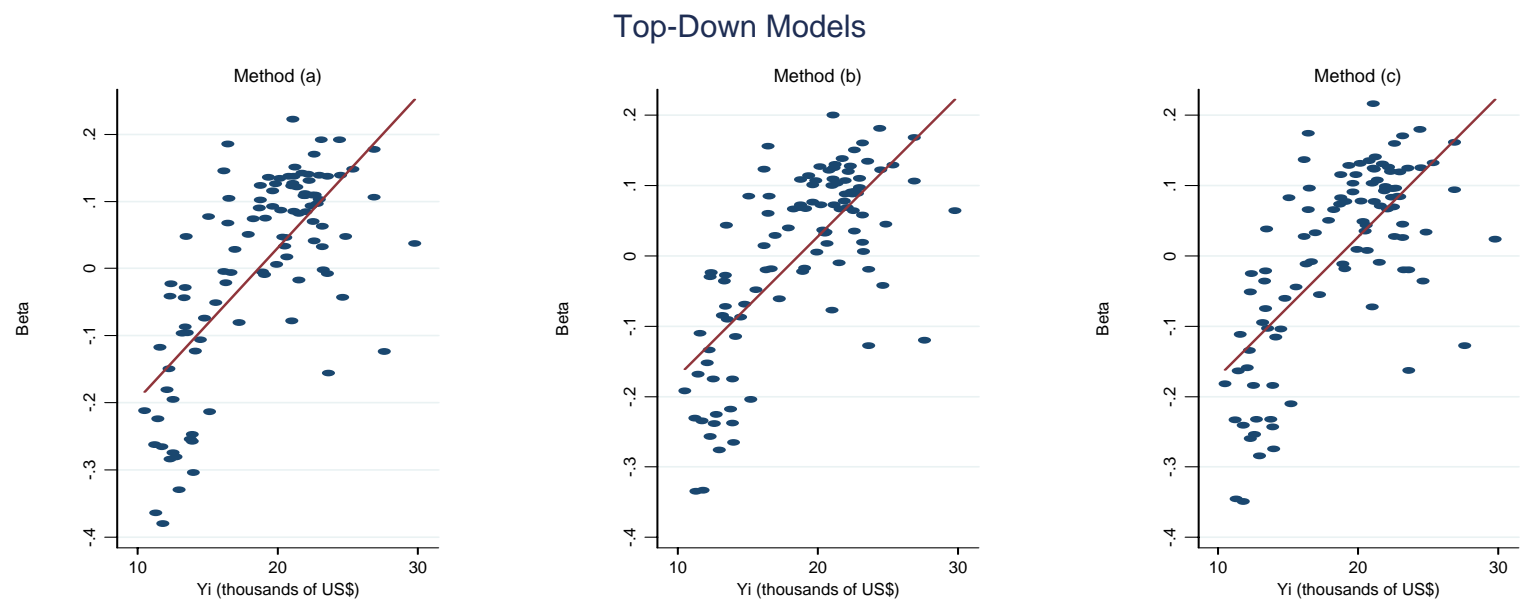

Bottom-Up Models: Provincial Level
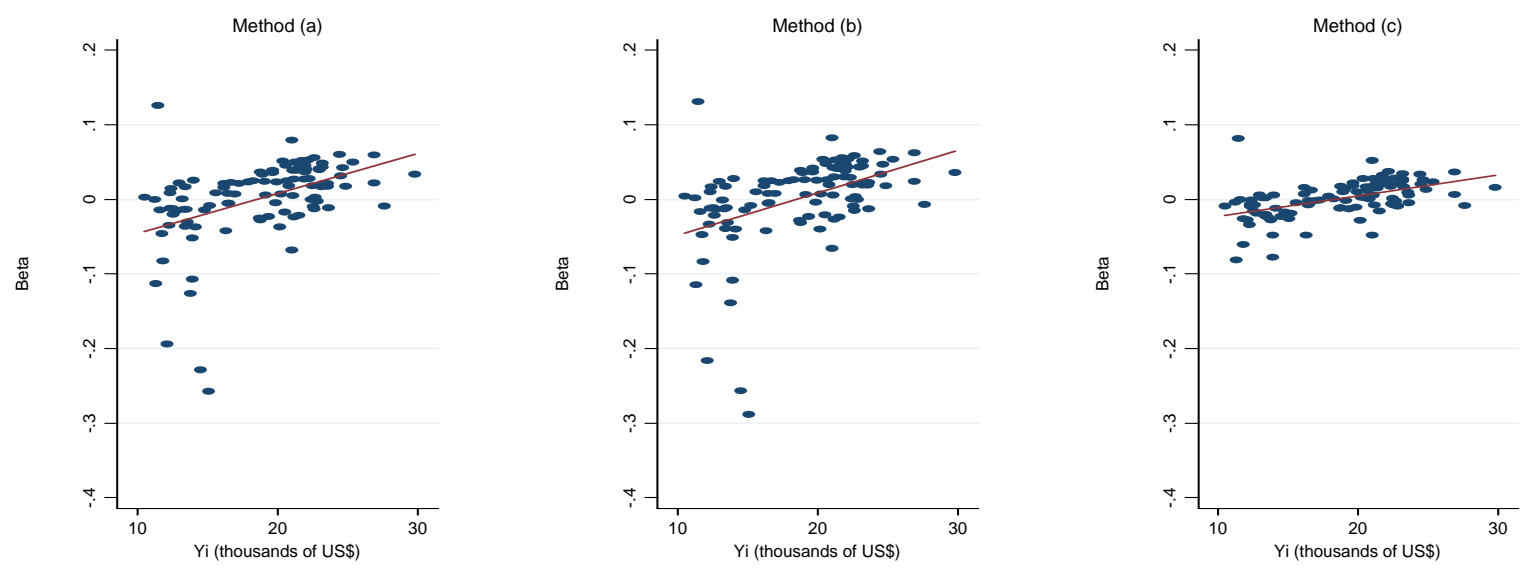

Table 5: Relationship between TC elasticities and average provincial per-capita income.

\begin{tabular}{lccc|ccc}
\hline & \multicolumn{3}{c}{ Top-Down } & \multicolumn{3}{c|}{ Bottom-Up: Provincial Level } \\
COEFFICIENT & $(\mathrm{a})$ & (b) & (c) & (a) & (b) & (c) \\
\hline Constant & -0.416 & -0.361 & -0.368 & -0.098 & -0.104 & -0.050 \\
& $(0.044)$ & $(0.039)$ & $(0.041)$ & $(0.021)$ & $(0.023)$ & $(0.0090)$ \\
$\mathrm{Y}_{\mathrm{i}} / \mathrm{N}_{\mathrm{i}}$ & 0.0223 & 0.0194 & 0.0197 & 0.0053 & 0.0056 & 0.0027 \\
& $(0.0023)$ & $(0.0020)$ & $(0.0021)$ & $(0.0011)$ & $(0.0012)$ & $(0.00047)$ \\
\hline Observations & 103 & 103 & 103 & 103 & 103 & 103 \\
$\mathrm{R}^{2}$ & 0.486 & 0.478 & 0.459 & 0.190 & 0.183 & 0.249 \\
\hline NOTE: $\mathrm{Y}_{\mathrm{i}} / \mathrm{N}_{\mathrm{i}}$ is the average over period $1995-2004$. Standard errors in parentheses: no-asterisk $\mathrm{p}<0.01 ; * \mathrm{p}<0.05 ; * * \mathrm{p}<0.1 ; * * * \mathrm{p}>0.1$. See text for \\
methods $(\mathrm{a}),(\mathrm{b})$, and $(\mathrm{c})$.
\end{tabular}


Figure 4: Map of distance elasticities of 103 Italian provinces.
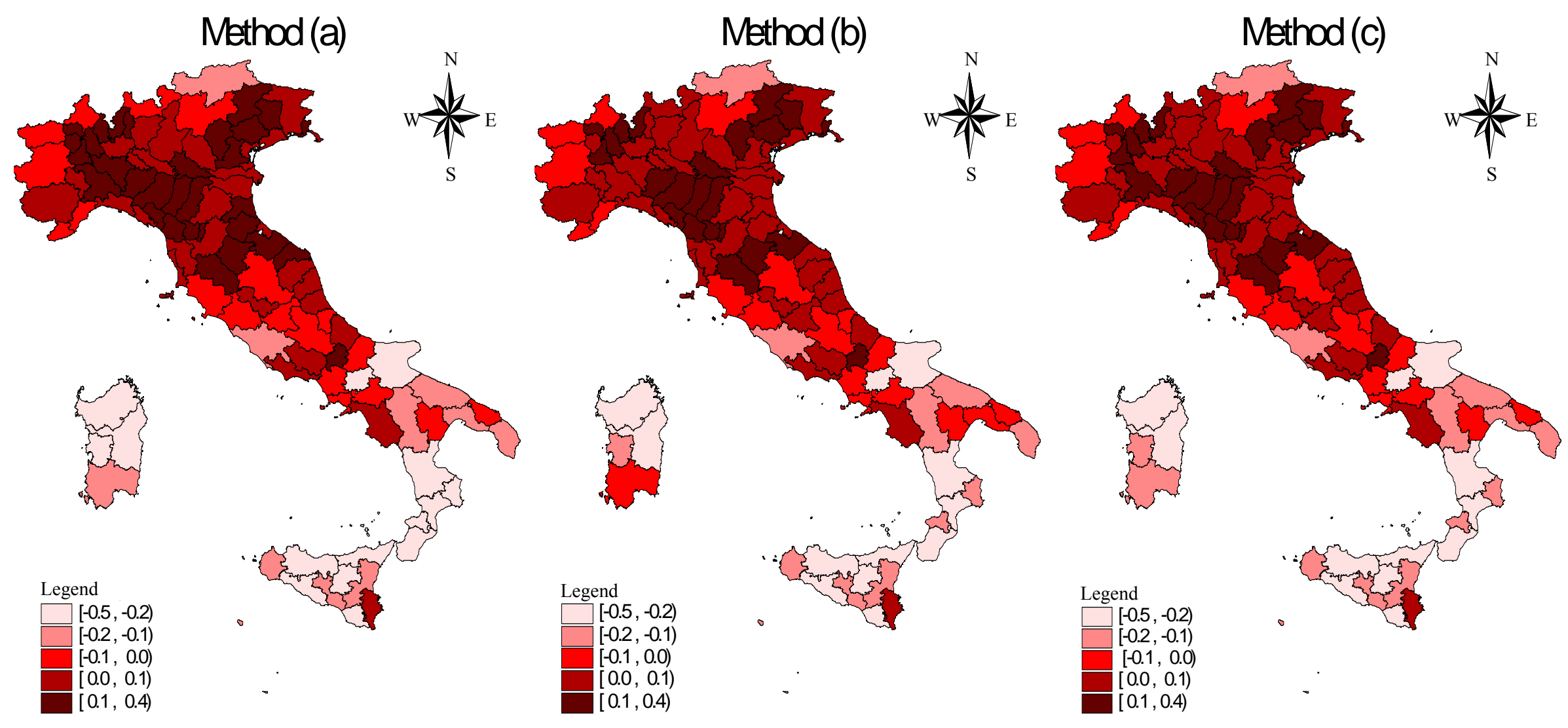

Note: Colors in the maps represent mean-adjusted provincial distance elasticities using the top-down model; see text for methods (a), (b), and (c); first and last ranges in the legend are larger than other ranges because they include extreme values. 